Original Research Paper

\title{
Barcode of Life Data Systems (BOLD) Versus GenBank Molecular Identification of a Dragonfly from the UAE in Comparison to the Morphological Identification
}

\author{
${ }^{1}$ Noora Almansoori, ${ }^{1,2}$ Mohamed Rizk Enan and ${ }^{1}$ Mohammad Ali Al-Deeb \\ ${ }^{1}$ Department of Biology, United Arab Emirates University, Al-Ain, UAE \\ ${ }^{2}$ Agricultural Research Center, Agricultural Genetic Engineering Research Institute, Giza, Egypt
}

\author{
Article history \\ Received: 26-09-2019 \\ Revised: 19-11-2019 \\ Accepted: 29-11-2019 \\ Corresponding Author: \\ Mohammad Ali Al-Deeb, \\ Department of Biology, United \\ Arab Emirates University, Al- \\ Ain, UAE \\ Email: m_aldeeb@uaeu.ac.ae
}

\begin{abstract}
Dragonflies are insects in the order Odonata. They inhabit freshwater ecosystems and are found in the UAE. To date, few checklists have been published for the local dragonflies and the used identification keys are not comprehensive of Arabia. The aim of this study was to provide a molecular identification of a dragonfly based on the mitochondrial Cytochrome c Oxidase subunit I (COI) gene using the National Center for Biotechnology Information (NCBI) database and the Barcode of Life Data Systems (BOLD) in comparison with the morphology. The insect's DNA was extracted and the PCR was performed on the target gene. The insect was identified initially as Anax imperator based on the NCBI database and as Anax parthenope based on the BOLD. However, the morphological identification was in agreement with the one produced by the BOLD. The results of this study is a demonstration of how, in some cases, the DNAbased identification does not provide a conclusive species designation and that a morphology-based identification is needed.
\end{abstract}

Keywords: Dragonfly, Anax imperator, Anax Parthenope, DNA Barcoding, COI Gene

\section{Introduction}

Dragonflies constitute the suborder (Anisoptera). They belong to the order Odonata, which includes other two suborders: Zygoptera (damselflies) and Anisozygoptera (Dijkstra et al., 2013). The Odonates were amongst the pioneers of flight in the animal kingdom; they showcase a unique flying mechanism and wing venation. They are equipped with unique copulatory structures and have complex and elaborate mating system, thus making them a heavily investigated subject of behavioral and ecological studies (Carle et al., 2015). In general, Odonates are characterized by having a large prognathic heads with large compound eyes, chewing mouthparts and setaceous antennae. Their prothorax (wingless thoracic segment) is small and functions as a neck, while the mesothorax and metathorax are fused into a large pterothoracic segment equipped with two pair of elongate wings (Abbott, 2009). Each segment produces a pair of legs that are pushed to the front, so it can form a basket used for hunting preys or perching (Pessacq, 2008). Anisoptera and Zygoptera have more morphological distinct characters beside the visible sturdiness of the prior's body. Zygopterous forewing and hindwing are about the same size, while the Anisopterous hindwings are basally broader than the forewings and have different venation patterns near the base, which are very helpful in identification. Their eyes usually touch on the top of the head (with the exception of the Petaluridae and Gomphidae) (Abbott, 2009). The abdomen (10 segments) includes the digestive and reproductive systems. Its length helps put more weight behind the wings for added aerodynamic swiftness. In all Anisoptera, sexual dimorphism is apparent in body weight; like all insects, the females are bigger and heavier than the males (Woodward, 2001). The Males have cleft on the ventral side of the second segment, which includes the copulatory structures. The spermaries are in the ninth segment. Whereas females have larger abdomens. Their reproductive tract is on the underside of the eighth segment and is covered by an ovipositor (Paulson, 2011). Dragonflies are considered excellent flyers exhibiting impressive flight skills. Thanks to their densely-veined hemolymph containing wings, they can make sufficient aerodynamic forces by periodically flapping the wings (Hou et al., 2017). 
Table 1: Compiled checklist of recorded Anisoptera species. three families exist; Gomphidae, Aeshnidae and Libellulidae. (*) are from (Feulner and Reimer, 2007), (**) from (Feulner and Judas, 2013) and the rest are from the first checklist (Giles, 1998)

\begin{tabular}{ll}
\hline Scientific name & Common name \\
\hline GOMPHIDAE & Arabian Lobetail \\
Paragomia tetraphylla & \\
Paragomphus genei & \\
AESHNIDAE & \\
Anax imperator & \\
Anax parthenope & Emperor \\
Hemianax ephippiger & Lesser Emperor \\
LIBELLULIDAE & Vagrant Emperor \\
Pantala flavescens & \\
Orthetrum sabina & Globe Skimmer \\
Orthetrum chrysostigma & Oasis Skimmer \\
Orthetrum taeniolatum & Girdled Skimmer \\
Orthetrum ransonneti $*$ & Azure (Blue) Skimmer \\
Diplacodes lefebvrei & \\
Trithemis annulata & Purple Darter \\
Trithemis arteriosa & Purple Blushed Darter \\
Trithemis kirbyi & Gulley Darter \\
Crocothemis erythraea & Orange Darter \\
Crocothemis sanguinolenta* & Carmine Darter \\
Selysiothemis nigra & Bloody Scarlet \\
Sympetrum fonscolombii* & Desert Darter \\
Urothemis thomasi $* *$ & Red-veined Darter \\
Zygonyx torridus & \\
\hline & Ringed Cascader \\
\hline &
\end{tabular}

Identifying by DNA barcode is superior to the conventional method in many aspects; some animals, like insects, go through morphologically distinct developmental stages making identification a bit tricky. In addition, numerous animals have accumulated genetic diversity without displaying it morphologically and molecular identification is not affected by these cryptic species or phenotypic plasticity. In some occasions, the species specimens might be damaged rendering them unrecognizable, so a small tissue sample for DNA barcoding can provide resolution. The theory of DNA barcodes is to find a single, universal segment of the DNA sequence for identification of all taxa. Despite the extensive research in this area, the perfect single and universal DNA barcoding marker has not been and most unlikely to be discovered. In 2013, the Barcode of Life Database (BOLD) included at least 2.7 million records of biological species. In the context of Anisoptera, Carle et al. (2015) published a phylogeny containing 510 species of 184 genera in 11 families by analyzing over 10,000 nucleotides from nuclear and mitochondrial genome (using COI).

The identification of dragonflies is typically done based on characteristics that are not readily seen in the field (Feulner and Reimer, 2007). Nevertheless, many species are clearly morphologically distinctive while others are ambiguous requiring a competent field observer. Morphological identification based on the coloration is sometimes complicated with Odonata. Colors are unreliable characteristic because some adults continue to lose their vibrant colors as they grow. Not to mention the newly emerged individuals, which may have different colors from that of an adult conspecific. Unfortunately, the only two resources for identification of the UAE's dragonflies are not comprehensive of Arabia and they exclude many dragonflies of Asian origins, which are usually locally found (Table 1). The aim of this study was to provide a molecular identification of a dragonfly based on the mitochondrial cytochrome $\mathrm{c}$ oxidase subunit I (COI) gene using the NCBI and BOLD databases in comparison with the morphology.

\section{Materials and Methods}

\section{Insect Collection}

The dragonfly specimen was captured manually from the vicinity of the Maqam Campus of the United Arab Emirates University, Al-Ain, United Arab Emirates (Lat.: 24.196221, Lng.: 55.679975) on the $19^{\text {th }}$ of March 2017.

\section{DNA Extraction and PCR}

Genomic DNA was extracted from the insect's leg muscle tissue using an automated DNA extraction machine Maxwell 16 (Promega, Madison, USA) according to the manufacturer's protocol. DNA was stored at $-20^{\circ} \mathrm{C}$. PCR reactions were conducted using the following oligonucleotide primer pair, which amplify a segment of the COI gene: LCO1490: 5'GGTCAACAAATCATAAAGATATTGG-3' and HCO2198: and TAAACTTCAGGGTGACCAAAAAATCA-3'

(Folmer et al., 1994). The template DNA was amplified in a $25 \mu \mathrm{L}$ reaction mixture containing $50 \mathrm{ng}$ of DNA, 10 pmol of each primer pair and $12.5 \mu \mathrm{L} 2 \mathrm{x}$ PCR Master Mix (Qiagen, Hilden, Germany). Reaction mixtures were preheated at $95^{\circ} \mathrm{C}$ for $5 \mathrm{~min}$. Amplifications were carried out for 35 cycles $\left(95^{\circ} \mathrm{C}\right.$ for $30 \mathrm{~s}, 45.5^{\circ} \mathrm{C}$ for $30 \mathrm{~s}$ and $72^{\circ} \mathrm{C}$ for $1 \mathrm{~min}$ ) and a final extension cycle at $72^{\circ} \mathrm{C}$ for $5 \mathrm{~min}$ in a Swift MaxPro thermocycler (ESCO, Singapore). Every PCR included a negative control (no-template DNA) to detect any contamination. Gel electrophoresis was performed using $1.5 \%$ agarose gel, which was stained by ethidium bromide. The bands on the gel were visualized on ultraviolet light transilluminator and the photograph was taken using a gel documentation system (Major Science, Taiwan).

\section{DNA Sequence Analysis}

PCR products were cleaned and sequenced (Sanger sequencing) by the Macrogen Company (Seoul, South 
Korea). Sequences were analyzed by Mega 6 software (Tamura et al., 2013), NCBI BLAST (http://blast.ncbi.nlm.nih.gov/Blast.cgi) and BOLD (http://www.boldsystems.org/).

\section{Results and Discussion}

The primer pair used in this study amplified the target region of the COI gene and produced the expected single band ( $\approx 700 \mathrm{bp}$ ) on the agarose gel (Fig. 1). The BLAST search of the DNA sequence revealed a $99 \%$ similarity with A. imperator at a sequence coverage $100 \%$ and an $E$-value $=0$ (Table 2). The sequence appeared in a big cluster of $A$. imperator on the neighbor-joining tree (Fig. 2). However, the BOLD database showed $99.84 \%$ similarity with $A$. parthenope (Table 3 ) and the sequence appeared in a cluster of $A$. parthenope on the phylogenetic tree (Fig. 3). Based on the morphology, the insect was identified as $A$. parthenope. The DNA sequence was submitted in the GenBank with an accession number MH669065.

The traditional taxonomic identification is based on morphological characters and often is a challenging and somewhat a daunting chore, which demands experienced taxonomists in order to be done accurately. About two decades ago, an innovative molecular tool has been developed for determining species and their phylogenies. It was based on DNA sequences of short standardized gene segments and was named DNA barcodes (Ajmal et al., 2014). In the UAE, DNA barcoding has been used in the identification of some arthropods (Al-Deeb and Enan, 2018; Al-Deeb et al., 2015).

In order to identify the dragonfly of this study using a molecular tool, the DNA sequence of a fragment of the COI gene was compared to other DNA sequences in the NCBI and BOLD databases. The BLAST search in the NCBI database showed $99 \%$ and $98 \%$ similarity with $A$. imperator and $A$. parthenope, respectively. Therefore, applying the $2 \%$ sequence similarity rule to this case will identify the sample as A. imperator based on the $99 \%$ DNA similarity and as A. parthenope based on the $98 \%$ DNA similarity. In addition, after conducting the multiple alignment the sequence appeared in a cluster of A. imperator on the neighbor-joining tree. However, according to the BOLD database the sequence appeared in a big cluster of $A$. parthenope on the phylogenetic tree. This demonstrated that in some cases identifying an organism based on DNA alone could show some identification differences between databases. However, in this study the final species designation was made based on morphology, which came in agreement with the DNA sequence similarity produced by the BOLD database. Thus, the insect sample was identified as a female $A$. parthenope. It had a yellow and green face and the S1 abdominal segment was yellowish green (Fig. 3).
On the forewing there were strong costa and nodus. The pterostigmas were present, thin and long and reddish brown in color (Fig. 4). In addition, the R3 vein was sharply curved directly under the pterostigma (Fig. 5). Moreover, there were two foliated anal appendages on the last abdominal segment. Furthermore, on the head, the occipital margin was slightly protruding and squarish with a tubercle at each side.

Although DNA-based species identification looks very appealing to non-experts in morphology-based taxonomy, it is not always successful. In such cases, its limitations can be overcome by morphological identification. Some studies highlighted and discussed the problems with the use of DNA barcodes for species delimitation (Brower, 2006; Will and Rubinoff, 2004; DeSalle et al., 2005). However, a group of taxonomists suggested the use of integrative taxonomy, which uses large number of characters including DNA (Will et al., 2005). We are in favor of this approach because it capitalizes on the power of the traditional taxonomy as well as the power of the DNA barcoding.

From a different perspective, this study shows that adults of $A$. parthenope are active in March, which is the time of the year in which temperatures are around mid to high thirties in the UAE, which is much milder compared to the ones in the summer. As predators, adults of $A$. parthenope feed on other insects, which are active during this time period because the spring season is a very biologically active time in the UAE.

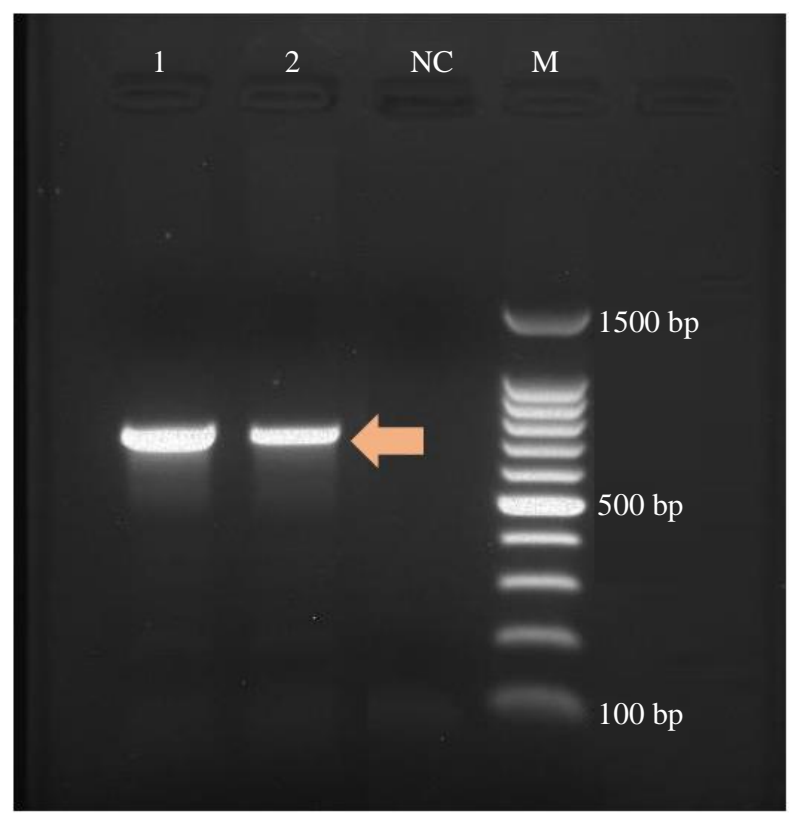

Fig. 1: Agarose gel (1.5\%) stained with ethidium bromide showing two bands of COI gene produced by the LCO1490 and HCO2198 primers and amplified by PCR. Lane M: 100-bp DNA ladder (Promega, Madison, USA); lane $\mathrm{NC}$ is negative control 


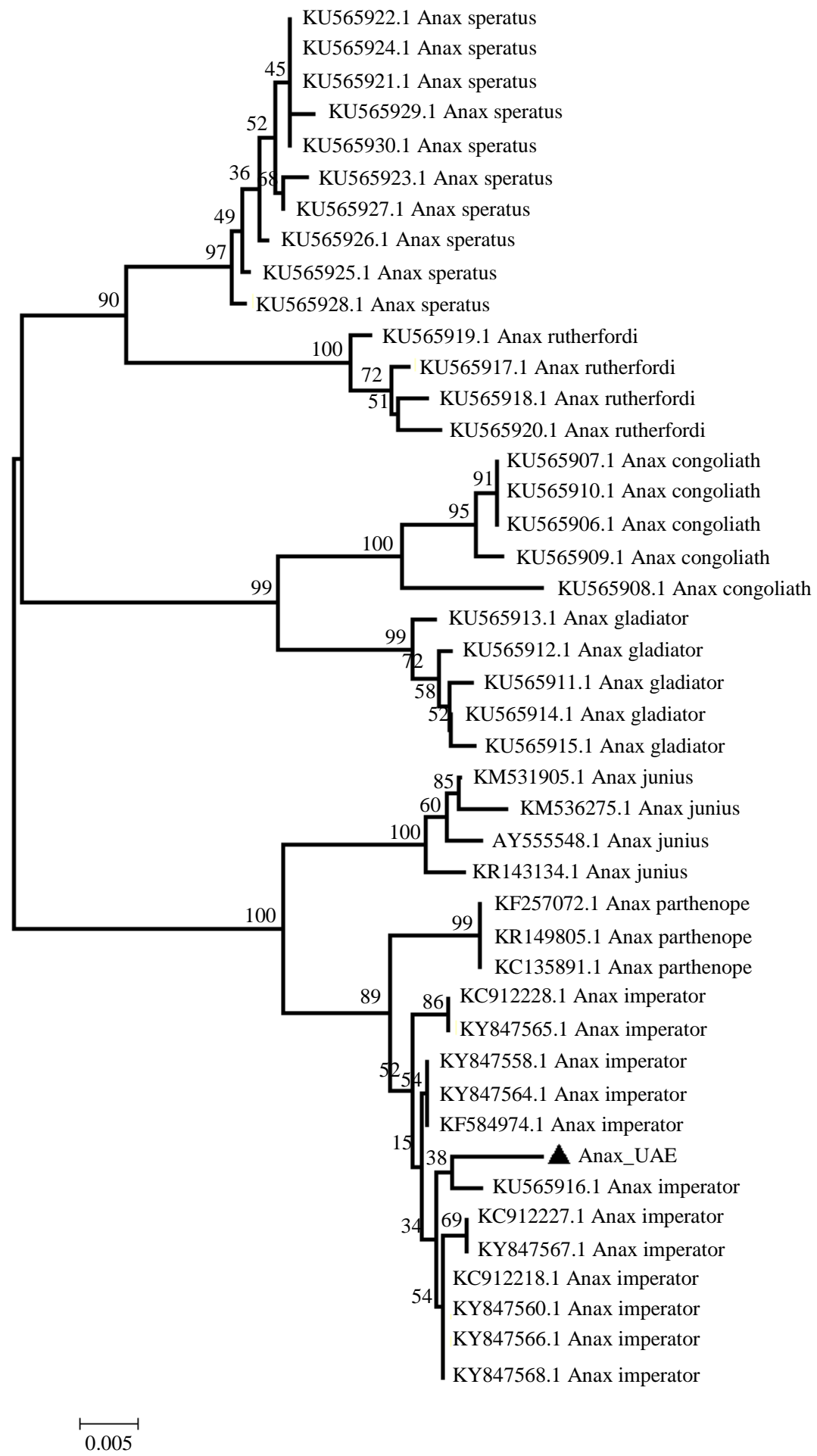

Fig. 2: Neighbor-Joining (Saitou and Nei, 1987) unrooted tree showing genetic similarity between the UAE dragonfly (MH669065) Cytochrome Oxidase subunit 1 (COI) gene and GenBank records. The percentage of replicate trees in which the associated taxa clustered together in the bootstrap test (1000 replicates) are shown next to the branches (Felsenstein, 1985). Genetic distances were computed using the Kimura 2-parameter method (Kimura, 1980) and are in the units of the number of base substitutions per site. Sequence alignments and tree generation were conducted in MEGA6 (Tamura et al., 2013). The dragonfly from the UAE is placed in a cluster of A. imperator 


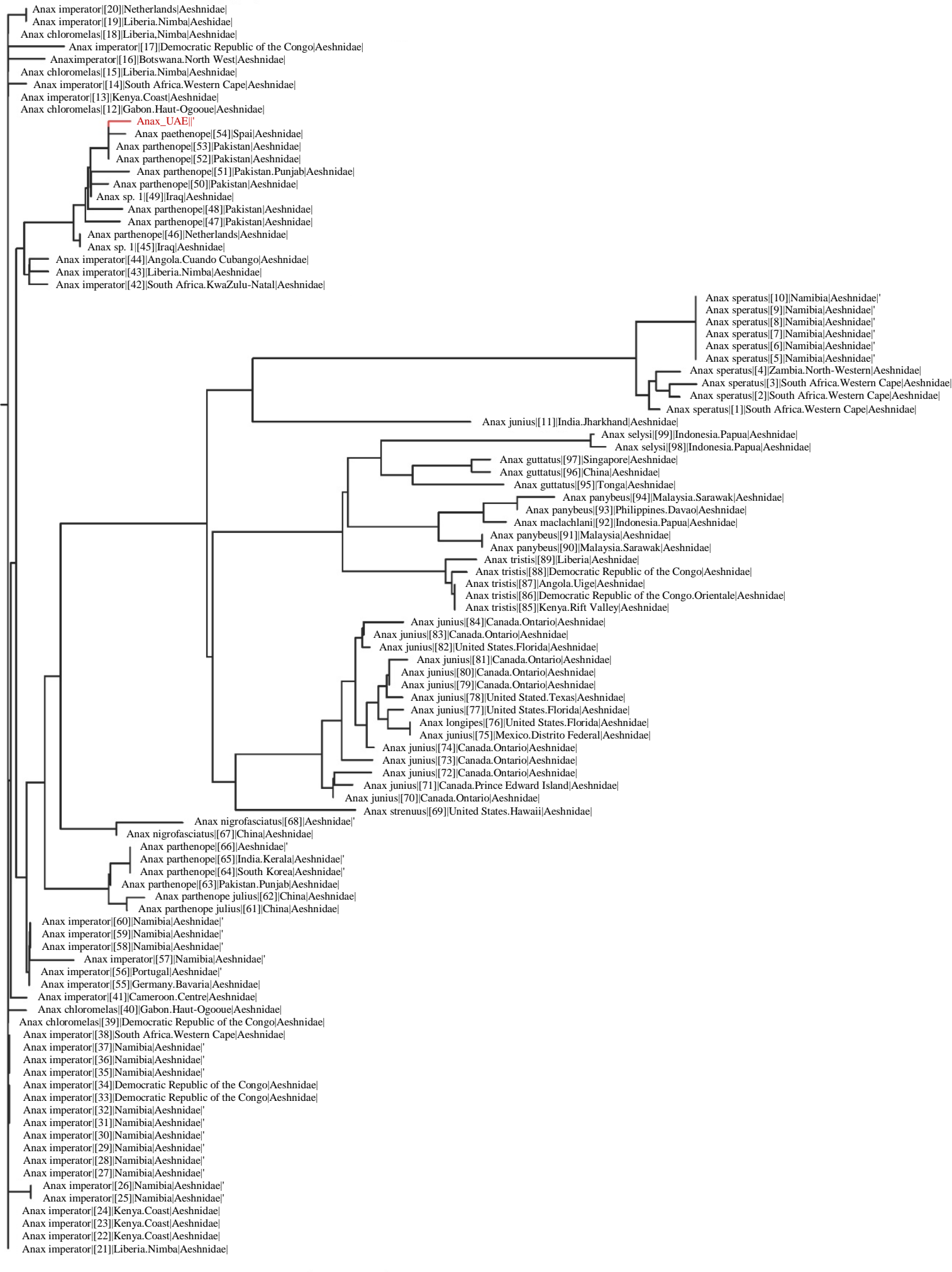

Fig. 3: Unrooted tree using Kimura 2 Parameter distance model produced by Barcode of Life Data System (BOLD). The dragonfly from the UAE is placed in a cluster of $A$. parthenope 


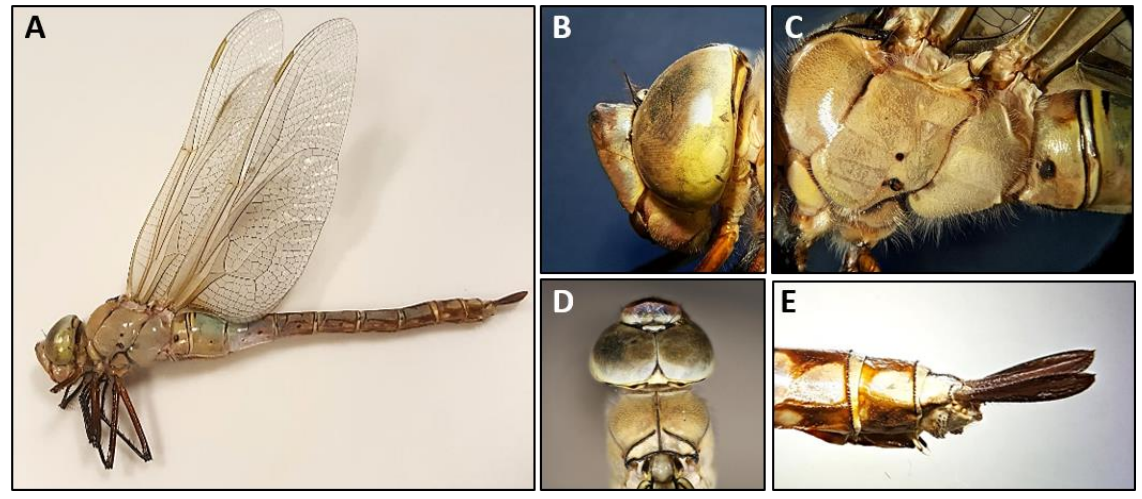

Fig. 4: Adult female of A. parthenope: (A) whole body (lateral), (B) head (lateral), (C) thorax (lateral), (D) head and prothorax (dorsal) showing occipital margin that is slightly protruding and squarish with a tubercle at each side and (C) the end of abdomen segments S8, S9 and S10 with two foliated anal appendages and the ovipositor underneath them

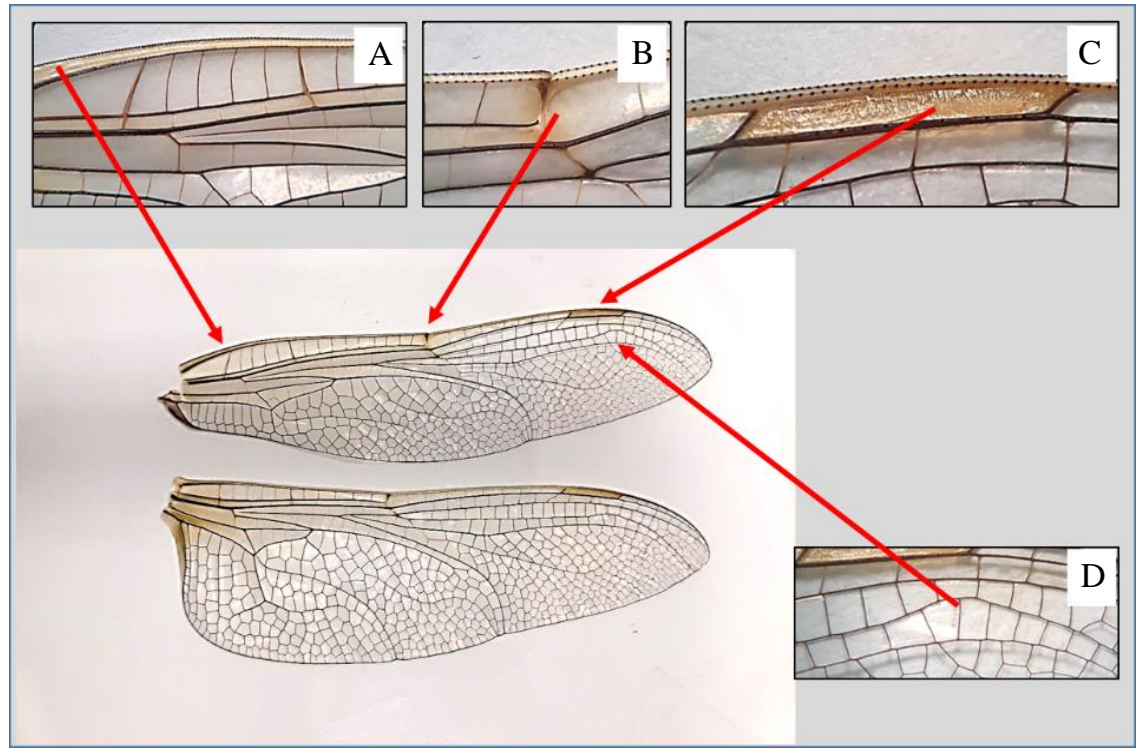

Fig. 5: Wings of female A. parthenope: (A) strong costa, (B) strong nodus, (C) prostigmas are thin and long and reddish brown in color and (D) the R3 vein is sharply curved directly under the pterostigma

Table 2: Molecular identification of a dragonfly from UAE as Anax imperator (MH669065) based on DNA similarity between cytochrome oxidase subunit 1 (COI) gene and GenBank species using NCBI BLAST

\begin{tabular}{|c|c|c|c|c|}
\hline Best match species & Accession number & Sequence identity & Sequence coverage & $E$-value \\
\hline Anax imperator mitochondrion, complete genome & KX161841.1 & $99 \%$ & $100 \%$ & 0 \\
\hline Anax imperator voucher RMNH.INS.502987 & KU565916.1 & $99 \%$ & $99 \%$ & 0 \\
\hline Anax parthenope voucher $\mathrm{P} 002$ & KC135891.1 & $98 \%$ & $99 \%$ & 0 \\
\hline Anax parthenope voucher CUAP 01-A1 & KR149805.1 & $98 \%$ & $96 \%$ & 0 \\
\hline Anax junius voucher ODON 0057.02 & KR143134.1 & $96 \%$ & $98 \%$ & 0 \\
\hline Anax imperator voucher DF_300 & KF584974.1 & $99 \%$ & $90 \%$ & 0 \\
\hline Aeshnidae sp. CC14A-07 & KX781748.1 & $96 \%$ & $98 \%$ & 0 \\
\hline Anax junius & AY555548.1 & $96 \%$ & $98 \%$ & 0 \\
\hline Anax tristis voucher RMNH.INS.502406 & KU565931.1 & $96 \%$ & $99 \%$ & 0 \\
\hline Anax imperator voucher Ai16D & KY847568.1 & $99 \%$ & $86 \%$ & 0 \\
\hline Anax imperator voucher Ai21A & KY847566.1 & $99 \%$ & $86 \%$ & 0 \\
\hline Anax imperator voucher Ai61A & KY847563.1 & $99 \%$ & $86 \%$ & 0 \\
\hline Anax imperator voucher Ai98A & KY847562.1 & $99 \%$ & $86 \%$ & 0 \\
\hline
\end{tabular}

Unless otherwise mentioned all the above sequences are cytochrome oxidase subunit 1 (COI) partial gene sequences. ${ }^{\text {a }}$ The typical threshold for a good $E$-value from a BLAST search is $10^{-5}$ or lower. 
Table 3: Molecular identification of a dragonfly from UAE as Anax parthenope based on DNA similarity between cytochrome oxidase subunit 1 (COI) gene and Barcode of Life Data System (BOLD)

\begin{tabular}{lllllll}
\hline Phylum & Class & Order & Family & Genus & Species & Similarity (\%) \\
\hline Arthropoda & Insecta & Odonata & Aeshnidae & Anax & parthenope & 99.84 \\
$=$ & $=$ & $=$ & $=$ & Anax & parthenope & 99.84 \\
$=$ & $=$ & $=$ & $=$ & Anax & sp. 1 & 99.68 \\
$=$ & $=$ & $=$ & Anax & parthenope & 99.68 \\
$=$ & $=$ & $=$ & Anax & sp. 1 & 99.52 \\
$=$ & $=$ & $=$ & Anax & parthenope & 99.52 \\
$=$ & $=$ & $=$ & Anax & parthenope & 99.52 \\
$=$ & $=$ & $=$ & Anax & parthenope & 99.35 \\
$=$ & $=$ & $=$ & Anax & parthenope & 99.35 \\
$=$ & $=$ & $=$ & Anax & parthenope & 99.35 \\
$=$ & $=$ & $=$ & Anax & imperator & 99.19 \\
$=$ & $=$ & $=$ & Anax & imperator & 99.07 \\
$=$ & $=$ & $=$ & Anax & imperator & 99.07 \\
\hline
\end{tabular}

It is rich in growing plants and their associated herbivorous insects and thus many organisms, including A. parthenope, try to utilize this growth conducive period before the arrival of the scorching summer. To our knowledge, this paper is the first molecular record of a dragonfly in the UAE. We hope it will encourage taxonomists to sequence the DNA barcodes of all the known dragonfly species in the country.

\section{Conclusion}

Although DNA barcoding has enough power to differentiate between intraspecific and interspecific variation, the current study is an example on how the DNA-based identification, in some cases, does not provide the accurate species identification and could assign the insect to the wrong species. In addition, it shows that the morphological identification can resolve problems arising from DNA-based identification. In short, integrative taxonomy could be the right middle ground.

\section{Acknowledgement}

The authors thank Wolfgang Schneider and Gary R. Feulner for assistance in the morphological identification of the dragonfly.

\section{Funding Information}

Consumables and equipment were provided by the United Arab Emirates University.

\section{Author's Contributions}

Noora Almansoori: Performed the laboratory work, provided an insect image (Fig. 4A) and participated in writing the manuscript.

Mohamed Rizk Enan: Participated in data analysis and in writing the manuscript.
Mohammad Ali Al-Deeb: Conceived and designed the study, collected insects, contributed reagents and tools, provided insect images, participated in the laboratory work, analyzed the data and wrote the manuscript.

\section{Ethics}

All the authors read and approved the manuscript. The authors declare no conflict of interest.

\section{References}

Abbott, J.C., 2009. Odonata (Dragonflies and Damselflies). In: Encyclopedia of Inland Waters, Likens, G.E. (Ed.), Academic Press, Oxford, pp: 394-404.

Ajmal, A.M., G. Gyulai, N. Hidvégi, B. Kerti and F.M.A. Al Hemaid et al., 2014. The changing epitome of species identification-DNA barcoding. Saudi J. Biol. Sci., 21: 204-231.

DOI: $10.1016 /$ j.sjbs.2014.03.003

Al-Deeb, M.A. and M.R. Enan, 2018. Genetic diversity in the camel tick Hyalomma dromedarii (Acari: Ixodidae) based on mitochondrial Cytochrome c Oxidase subunit I (COI) and Randomly Amplified Polymorphic DNA Polymerase Chain Reaction (RAPD-PCR). Adv. Entomol., 6: 285-294.

Al-Deeb, M.A., S.B. Muzaffar, Y. Abu Zeid, M.R. Enan and S. Karim, 2015. First record and prevalence of Rickettsia sp. and Theileria annulata in Hyalomma dromedarii (Acari: Ixodidae) ticks in the UAE. Florida Entomol., 98: 135-139.

Brower, A.V.Z., 2006. Problems with DNA barcodes for species delimitation: 'Ten species' of Astraptes fulgerator reassessed (Lepidoptera: Hesperiidae). Syst. Biodivers, 4: 127-132. DOI: $10.1017 / \mathrm{S} 147720000500191 \mathrm{X}$

Carle, F.L., K.M. Kjer and M.L. May, 2015. A molecular phylogeny and classification of Anisoptera (Odonata). Arthropod Syst. Phylogeny, 73: 281-301. 
DeSalle, R., M.G. Egan and M. Siddall, 2005. The unholy trinity: Taxonomy, species delimitation and DNA barcoding. Phil. Trans. R. Soc. B., 360: 1905-1916. DOI: 10.1098/rstb.2005.1722

Dijkstra, K.B., G. Bechly, S.M. Bybee, R.A. Dow and H.J. Dumont et al., 2013. The classification and diversity of dragonflies and damselflies (Odonata). In: Zhang, Z.-Q. (Ed.) Animal biodiversity: An outline of higher-level classification and survey of taxonomic richness. Zootaxa, 3703: 36-45. DOI: $10.11646 /$ zootaxa.3703.1.9

Felsenstein, J., 1985. Confidence limits on phylogenies: An approach using the bootstrap. Evolution, 39: 783-791.

Feulner, G.R., R.W. Reimer and R.J. Hornby, 2007. An updated illustrated checklist of dragonflies and damselflies of the UAE. Tribulus, 17: 37-62.

Feulner, G.R. and J. Judas, 2013. First UAE records of two Odonata: The dragonfly, Urothemis thomasi and the damselfly Ischnura nursei. Tribulus, 21: 4-13.

Folmer, O., M. Black, W. Hoeh, R. Lutz and R. Vrijenhoek, 1994. DNA primers for amplification of mitochondrial cytochrome c oxidase subunit I from diverse metazoan invertebrates. Molecular Marine Biol. Biotechnol., 3: 294-299.

Giles, G.B., 1998. An illustrated checklist of the damselflies and dragonflies of the UAE. Tribulus, 8: 9-15.

Hou, D., Z. Zhong, Y. Yin, Y. Pan and H. Zhao, 2017. The role of soft vein joints in dragonfly flight. J. Bionic Eng., 14: 738-745.

DOI: $10.1016 / \mathrm{S} 1672-6529(16) 60439-0$
Kimura, M., 1980. A simple method for estimating evolutionary rate of base substitutions through comparative studies of nucleotide sequences. J. Mol. Evol., 16: 111-120.

Paulson, D., 2011. Dragonflies and Damselflies of the East. 1st Edn., Princeton University Press, Princeton, ISBN-10: 1400839661, pp: 544.

Pessacq, P., 2008. Dragonfly genera of the new world: An illustrated and annotated key to the anisoptera. Rev. Chil. Hist. Nat., 81: 151-52. DOI: $10.4067 / \mathrm{S} 0716-078 X 2008000100012$

Saitou, N. and M. Nei, 1987. The neighbor-joining method: A new method for reconstructing phylogenetic trees. Mol. Biol. Evol., 4: 406-425.

Tamura, K., G. Stecher, D. Peterson, A. Filipski and S. Kumar, 2013. MEGA6: Molecular evolutionary genetics analysis version 6.0. Mol. Biol. Evol., 30: 2725-2729.

Will, K.W. and D. Rubinoff, 2004. Myth of the molecule: DNA barcodes for species cannot replace morphology for identification and classification. Cladistics, 20: 47-55.

Will, K.W., B.D. Mishler and Q.D. Wheeler, 2005. The perils of DNA barcoding and the need for integrative taxonomy. Syst. Biol., 54: 844-851. DOI: $10.1080 / 10635150500354878$

Woodward, G., 2001. Dragonflies: Behavior and ecology of odonata. Freshw. Biol., 46: 141-43.

DOI: $10.1111 / \mathrm{j} .1365-2427.2001 .00664 . \mathrm{x}$ 